\title{
THE CORRELATION STUDY OF STUDENTS' LEARNING STYLES AND ENGLISH
} ACHIEVEMENT

\author{
Dzul Rachman ${ }^{1}$, AniqHudiyahBil Haq ${ }^{1}$, Rio Arif Pratama ${ }^{1}$, Bayu Prasetyo ${ }^{1}$ \\ ${ }^{1}$ Universitas Muhammadiyah Kalimantan Timur \\ Email:dr650@umkt.ac.id
}

\begin{abstract}
This research aimed to find out the students learning styles, the English achievement, and the correlation between students' learning styles and English achievement of the second-semester students of University of Muhammadiyah Kalimantan Timur. The design of this study was quantitative research with a correlation design. The sample of the study was 56 students. The instruments of the study were the questionnaire of students' learning styles and English achievement test. In order to make data become linear, the researcher converted those data into Z-score and then correlated the converted data using correlate bivariate. The result of the study showed that the mean score of students' learning styles was 50, that means fair. There were 21 students $(38 \%)$ preferred visual learning styles, 15 (27\%) of students preferred reading learning styles, $13(23 \%)$ students preferred kinesthetic learning styles, 4 (7\%) students preferred auditory learning styles and $3(5 \%)$ preferred used two learning styles. Thus, the mean score of students' English achievement was 50, that means fair. It means that, there was a significant correlation between students' learning styles and English achievement. Based on the finding above, it is suggested to language learner to be familiar with their learning styles so that they can benefit the strength of styles and manipulate the weakness of styles. For language teacher, they may take learners style into account for the sake of different learning strategies in the classroom so that they can promote learner's need.
\end{abstract}

Keywords: English achievement, learning style, university level

\section{INTRODUCTION}

Students learn in diverse ways; each of them has different styles or preferences in the way they recognized and process information. Taking into considerations the different style preferences students have is of prevailing significant in the teaching-learning progression.

In literature, there exist numerous learning styles and learning style models. Learning style is a student's consistent way of responding to and using stimuli in the context of learning. Moreover, he states that learning styles also can be considered as a good predictor of academic performance, and it should be taken into account to improve students' performance, specifically 
in learning a second language. Pritchard (2008) explains that learning style is a particular way in which an individual learns or best manner in which to think, process information, and demonstrate learning.

A study of Bilgin and Durmus (2003) under the title "A Comparative Research on Learning Styles and the Success of Students" has shown that there is a statistically significant relationship between collaborative and independent learning style and academic success, and a negative correlation between dependent learning style and general academic success. Effective learning styles can be taught. The teacher can help students by showing effective note taking, by guiding them for effective class discussion, helping them on preparing for exams, etc. Teachers should arrange learning environment to facilitate collaborative and independent learning style. Students having different learning styles can be joined in a way they can share their styles. Furthermore, a research conducted by Zywno\&Waalen (2002), under the title "The Effect of Individual Learning Styles on Student Outcomes in Technology-enabled Education," was found that the largest increases in achievement were found among students with active, sensing and global learning styles. So, it is beneficial for the researcher to conduct a study about the correlation study of students' learning styles and English achievement in university level.

\section{METHOD}

\section{Research Design}

The design of this research was quantitative research with correlational design. According to Urdan (2005), a correlation study simply means that variation in the scores on one variable corresponds with variation in the scores on the second variable. It refers to a study in which the purpose is to discover the relationship between two or more variables. In this study, there are two variables, students' learning styles as an independent variable (X) and an English achievement as a dependent one (Y).

The design of the correlational study will be illustrated as follows:

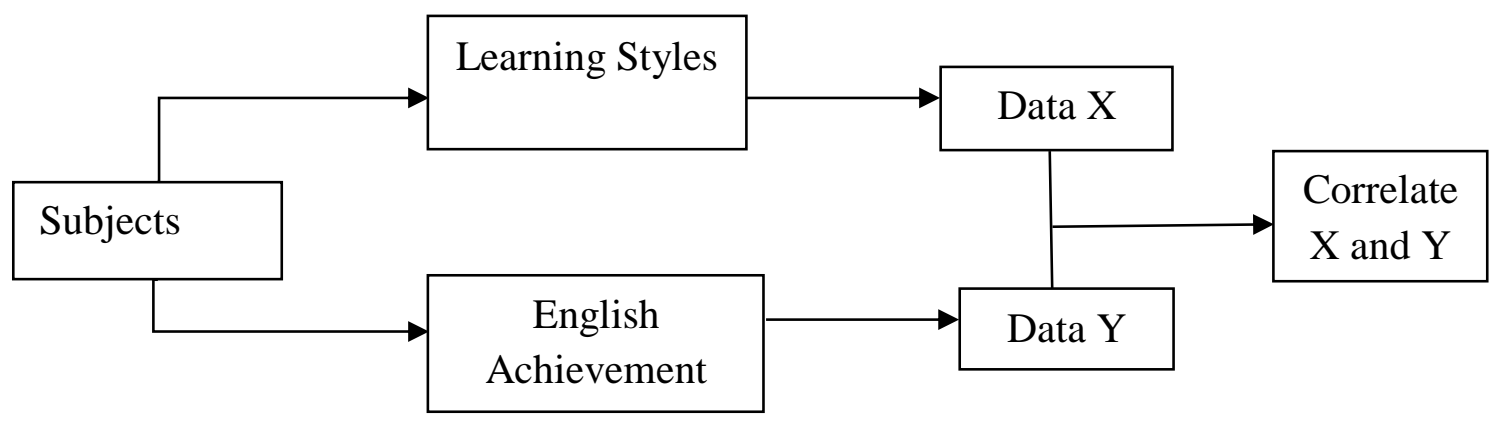




\section{Sample}

In taking samples, the researcher followed Gay (2012) opinion who stated that in general, the minimum number of subjects believes to be acceptable for a study depends on upon the type of research involved. For this study, the researcher took 56 students as the sample from the psychology and law department. Therefore, the researcher using a purposive sampling technique

\section{Research Instruments}

In this research, the researcher used the questionnaire to collect the data about students' learning styles and English achievement test. For English achievement test used multiple choices test type. The test consists of 60 items. The questionnaire took and adapted from McVay's Learning Style Survey (2001). The learning styles that measured are visual learning style, auditory learning style, reading learning style, and kinesthetic learning style (VARK learning styles). The reason the researcher chooses these learning styles because it is modified by classifying students to four different modes based on different senses, namely visual, aural, reading, and kinesthetic. The questionnaire was scored using a Likert scale.

In this study, the questionnaire use point value as follow:

Table 1.Scoring of the option

\begin{tabular}{|l|c|c|c|c|}
\hline & Always & Often & Seldom & Never \\
\hline Positive Statement & 4 & 3 & 2 & 1 \\
\hline Negative Statement & 1 & 2 & 3 & 4 \\
\hline
\end{tabular}

The distribution of the questionnaire as follows:

Table 2. Item indicators of the questionnaire

\begin{tabular}{|l|l|c|}
\hline No & Indicators & Number of Statements \\
\hline 1 & Visual learning style & 20 \\
\hline 2 & Auditory Learning style & 20 \\
\hline 3 & Reading learning style & 20 \\
\hline 4 & Kinesthetic learning style & 20 \\
\hline & Total & 80 \\
\hline
\end{tabular}




\section{Data Collection Techniques}

In collecting the data, the researcher followed several steps to collect the data. First, the researcher prepares the items of the questionnaire of students' learning styles and English achievement test. Second, the researcher conducted the tryout. The researcher gave 80 items questionnaire of students' learning styles and 60 items of English achievement test to the 15 students who are not included as a sample. Then the researcher got the result to find out validity and reliability of the instruments using the SPSS program. Fourth, the researcher gave the revised questionnaire of students' learning styles and English achievement test to the sample. Fifth, the researcher calculated the questionnaire by calculating the score from each statement based on Likert scale point values. Then, the researcher scored the English achievement test. The last, the researcher correlated the scores of students' learning styles and English achievement used correlate bivariate.

\section{Data Analysis Technique}

In order to make the raw score from the questionnaire and the English achievement directly comparable, the raw score would be converted into a standard score ( $\mathrm{Z}$ scores). To convert the scores of the questionnaire and the English test,the researcher used descriptive statistics on SPSS. To see the correlation between those variables, the researcher used bivariate correlation.

\section{FINDINGS AND DISCUSSION}

\subsection{Finding of Students' Learning Styles}

The researcher got the result of students' learning styles by using a questionnaire. The researcher used the Likert scale to score the questionnaire of students' learning styles. Then the data of the questionnaire were converted into Z-score to make the data become linear one to the data of English achievement test.

The following table presents the frequency and the percentage of each classification of students' learning styles: 


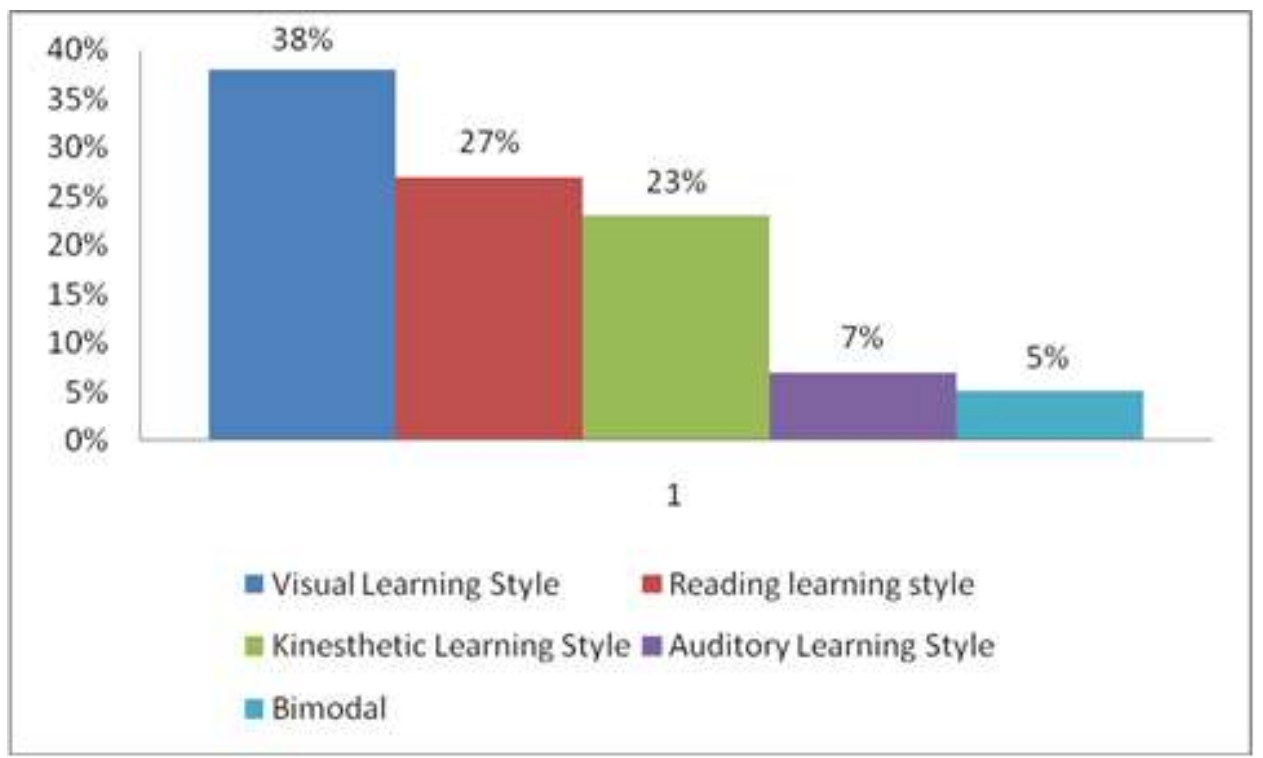

The table showed that from the number of 56 samples only 5 students got a very high score (9\%), 12 students got a high score (21\%), 19 students got a fair score (34\%), 18 students got low score (32\%), and only 2 students got deficient score (4\%). The highest raw score of students' learning styles questionnaire was 174 , and the lowest one was 110 . The mean score was 137.2. Furthermore, the highest Z-score of students' learning styles questionnaire was 74.37, and the lowest one was 31.95. The mean score was 50.00 (fair).

\subsection{Finding of the Students' English Achievement}

Measuring the English achievement used a summative test based on the lesson plan. The materials were that students already studied.

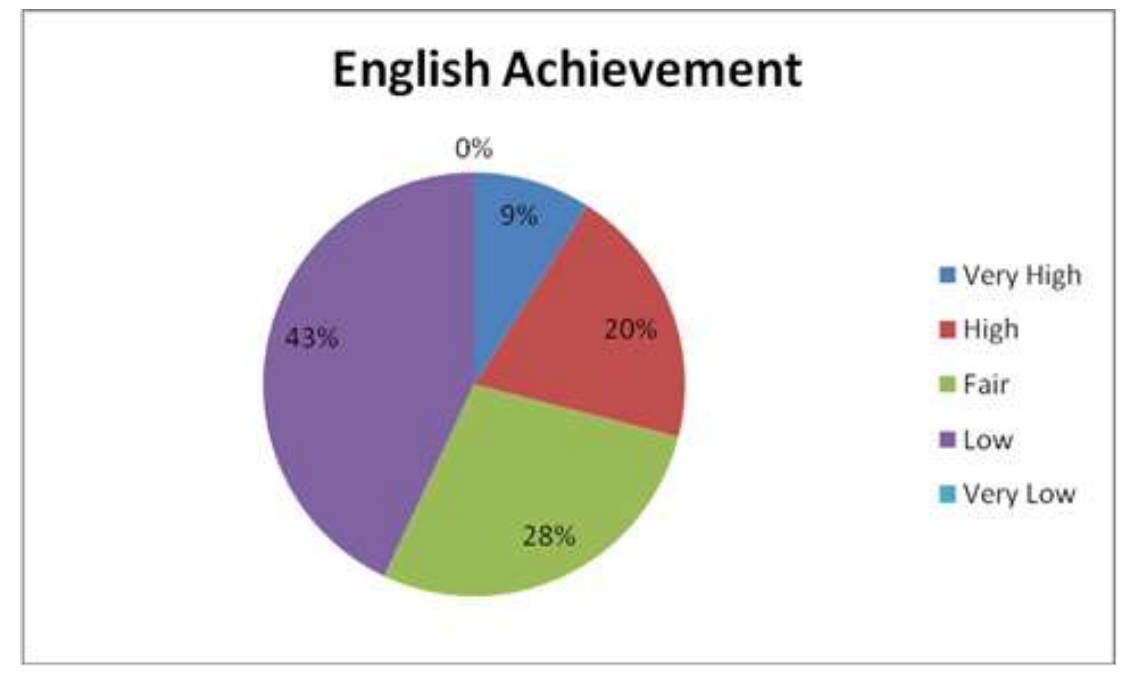


From the number of 56 samples, the highest raw score of students' English achievement was 96.67, and the lowest one was 56.67. The mean score was 72.4.

Furthermore, the highest Z-score of students' English achievement was 73.03, and the lowest score was 35.03. The mean score was 50. Can we conclude that the students' English achievement was fair.

\subsection{Findings Correlation between Students' Learning Styles and English Achievement}

After obtaining the score of the questionnaire of students' learning styles, the researcher correlates the score with the data of students' English achievement to find out the correlation between both of them using Pearson Product Moment Correlation on SPSS.

Table 3. Descriptive Statistics

\begin{tabular}{|l|r|r|r|}
\hline & Mean & Std. Deviation & N \\
\hline T_questionnaire & 50,0000 & 10,00000 & 56 \\
\hline T_test & 50,0000 & 10,00000 & 56 \\
\hline
\end{tabular}

Table 4. Correlations

\begin{tabular}{|l|l|r|r|}
\hline \multicolumn{2}{|c|}{} & T_Angket & \multicolumn{2}{c|}{ T_Test } \\
\hline \multirow{5}{*}{ T_questionnaire } & Pearson Correlation & 1 &, $626^{* *}$ \\
\cline { 2 - 4 } & Sig. (2-tailed) & &, 000 \\
\cline { 2 - 4 } & $\mathrm{N}$ & 56 & 56 \\
\hline \multirow{2}{*}{ T_test } & Pearson Correlation &, $626^{* *}$ & 1 \\
\cline { 2 - 4 } & Sig. (2-tailed) & 5600 & 56 \\
\cline { 2 - 4 } & $\mathrm{N}$ & 56 & \\
& & &
\end{tabular}

When the correlation coefficient close to +1.00 means that there is a positive relationship between questionnaire of students' learning styles (X) and English achievement test (Y). In contrast, when the correlation coefficient close to -1.00 it means that there is a negative relationship between these two variables. To determine the closeness of the relationship between variables can be identified using the interval correlation coefficient and the interpretation by Rumsey (2011).

Table 5. R Value Interpretation

\begin{tabular}{|c|l|}
\hline R Value & \multicolumn{1}{|c|}{ Interpretation } \\
\hline $0.00-0.200$ & No linear relationship \\
\hline $0.300-0.400$ & A weak uphill (positive) linear relationship \\
\hline $0.500-0.600$ & A moderate uphill (positive) linear relationship \\
\hline $0.700-0.900$ & A strong uphill (positive) linear relationship \\
\hline 1.00 & A perfect uphill (positive) linear relationship \\
\hline
\end{tabular}


Based on the table of correlation above, the students' learning styles and English achievement scores are achieved by the students were calculated by using Pearson Product Moment Correlation. The result showed that the correlation between students' learning styles and English achievement was 0.626, and the significant value was 0.000. So, based on the $r$ value interpretation, the correlation can be classified as a moderate uphill linear relationship.

\section{CONCLUSIONS}

Learning style has an essential place in the lives of individuals. When the individual knows his/her learning style, s/he will integrate it in the process of learning so s/he will learn more efficiently and fast and will be successful (Gilakjani, 2012). The students' learning styles were found from were their answer in the questionnaire. The researcher gained data that there are four learning styles were identified, namely visual learning style, auditory learning style, reading learning style, and kinesthetic learning style.

Two factors affect the success of someone in learning a foreign language. The first factor is called external factors, and the second factor is called internal factors. Internal factors are factors in the students themselves. Carrol (2009) states that in addition to the factor above, one of the internal factors that are considered highly influential on the success of someone learning a foreign language is students learning styles. Learning styles are preferences, and potential or a tendency is used a person in learning.

From the finding of the study, it seems that student' learning styles and English achievement has a significant correlation. In another word, someone' learning styles does significantly affect her or his success in learning, especially in learning English. The result of this study supports the finding from (Ahmad, 2012) that there are several factors which influence the success of language learning, including learning style and learning strategy. Wibowo (2013) also conclude that the learning style of students to college English has a positive relationship and significant with English achievement. He stated that if learner learns English match with their learning style, so there is tend the students will have good skill in English.

There might be some reason why the present study correlates. Instructors can be one of the factors affecting English achievement. For example, whether or not they encourage the students to answer in the English language, whether they only use the English language to 
communicate with the students inside the class or whether let the students use their L1 sometimes to express what they cannot in English (Hamad, 2013). If a teacher teaches using various method and strategies which cover all of the students' learning styles, it may help students to understand the material. In other words, the way the teacher delivers the lesson is appropriate for the way students receives the information. Students can prefer one, two, or three learning styles. Because of these different learning styles, it is crucial for teachers to incorporate in their curriculum activities related to each of these learning styles so that all studentscan succeed in their classes (Gilakjani, 2012). While we use all of our senses to take in information, we each seem to have preferences in how we learn best.

From the conclusion above, the researcher would like to give some suggestions concerning the result of the study. By knowing that the students' learning styles relate to English achievement, the students should realize their learning styles. If the students want to have better achievement, they have to learn based on their learning styles. Then, Since the students' learning styles can influence the students' English achievement, the lecturer should become more pay attention to their students. The lecturer should be aware that students learn and receive a lesson in different ways. They are knowing the learning styles of each his/her students so they can decide the appropriate method and strategies in teaching. Moreover, the lecturer should incorporate in their curriculum activities related to each of the learning styles so that all students can succeed in their classes.

\section{ACKNOWLEDGMENTS}

The researchers put grateful to head of Psychology department, Law department in University Muhammadiyah Kalimantan Timur that facilitates the researcher to conduct this research. We would also like to extend thanks to anonymous reviewers for their critical reviews that significantly improved the manuscript.

\section{REFERENCES}

Ahmad,O. N. (2012). The Effect of Different Learning Styles on Developing Writing Skills of Saudi Learners. British Journal of Arts and Social Sciences, 5(2).

Bilgin, I \& Durmus, S. (2003). A Comparative Research on Learning Styles and the Success of Students.

Carroll, J.B (2009). Cognitive abilities in foreign language aptitude: Then and now. In: T.S. 
Parry and C.W. Stansfield (Eds.), Language aptitude reconsidered (pp.11-29). Englewood Cliffs, NJ: Prentice-Hall.

Gay, L.R., Mills, G.E. and Airasian, P. (2012) Educational Research Competencies for Analysis and Applications. Pearson, Columbus.

Gilakjani, A.P (2012). Visual, Auditory, Kinaesthetic Learning Styles and Their Impacts on English Language Teaching. Journal of Studies in Education ISSN 2162-6952 2012, Vol. 2, No. 1 .

Hamad, M. M (2013). Factors Negatively Affecting Speaking Skills at Saudi Colleges for Girls in The south. Canadian Center of Science Education, 6(12).Lawrance Erlbaum Associates, N. J., ISBN: 0-8058-3431-1, 276.

MacCarter, K.M. (2008). The Effect of auditory stimulation on learners with different learning styles. Capella University, Doctor of Philosophy

McVay, M. (2001). How to be a successful distance leaming student: Leaming on the Intemet. New York: Prentice Hall.

Penger, S. and Tekavčič, M. (2009). Testıng Dunn \& Dunn's And Honey \& Mumford's Learning Style Theories: The Case Of The Slovenian Higher Education System. Management, Vol. 14, 2009, 2, pp. 1-20.

Pritchard, Alan. (2008). Ways of learning. Learning theories and learning styles in the classroom. Second edition (41)

Urdan, T. C. (2005). Statistics in Plain English (second edition). New Jersey: Lawrence Erlbaum Associates Publisher.

Wibowo, Y.W (2012) The Correlation Between Students' Motivation And Learning Styles Towards Students' English Achievement. The State Polytechnic Of Lampung. Science Journal, vol 7.

Zywno, M.S. \& Waalen, J.K. (2002). The Effect of Individual Learning Styles on Student Outcomes in Technology-enabled Education. Global J. of Engng. Educ., Vol.6, No.1. 